\title{
Impact of institutional quality on economic performance of Eastern Africa: a panel data analysis
}

\author{
Fikadu Abera; Wondaferahu Mulugeta; Tesfaye Melaku* \\ Department of Economics, Jimma University, Ethiopia \\ *To whom correspondence should be addressed.Email: tesamelua@ gmail.com
}

\begin{abstract}
Nowadays, studies argued that international difference in prosperity across a country is the matter institutional quality. Thus, the poor economic performance of African's is linked to their weak institutional quality. The aim of this study is to examine the extent to which institutional quality affect economic performance of 14 selected East African Countries; Burundi, Comoros, Djibouti, Ethiopia, Kenya, Madagascar, Malawi, Mozambique, Mauritius, Rwanda, Tanzania, Uganda, Zambia and Zimbabwe, over the period 2005-2016, using fixed effect and System GMM methods. The finding of this study confirms with the existing empirical study that economic institutions matter for economic performance among which control of corruption and government effectiveness has positive impact on economic performance, while rule of law has adverse impact. The finding of this study implies that that Eastern Africa with better institutions has a higher economic performance. Therefore, the Eastern Africa countries should improve those institutions that have positive impact, and promote and change those institutions that have adverse effect in way that it can promote economic development.
\end{abstract}

Key words: Eastern African, Economic performance, Institutional quality, Panel data analysis, System GMM

JEL Classifications: E02, O11, O55

\section{INTRODUCTION}

The cause of international difference in economic growth and development is the most important concern in social sciences. Many years ago, economist recognized that capital accumulation and exogenous technical progress are the main reason behind cross-country difference in international economic development. Subsequently, the debate was extended to the quality of policy and incentive structure that enable a county to accumulate more capital and innovate. In the recent time, institutional frame works affecting these policies and incentives was found to be the root cause behind difference in economic growth and development (Acemoglu \& Robinson, 2010)."Institutions are the rules of the game in a society or, more formally, are the humanly devised constraints that shape human interaction and in consequence they structure incentives in human exchange, whether political, social, or economic" (North, 1990).

Today, the role of institution in economic performance attracted the attention of many researchers, policy makers and development practitioners. A growing body of the literatures established that Institutions are fundamental determinant of the welfare of nations, because they affect organization performance by fostering better policy choice. 
They are created to establish incentive structure that help to reduce transaction cost, minimize uncertainty and promote efficiency, maintain social harmony, hence contribution to strong economic performance of a nations. When they weak uncertainty, unpredictability, instability, corruption and transaction costs increase (Wiggins \& Davis, 2006; Tadic, 2006; Acemoglu \& Robinson, 2010; Vītola \& Senfelde, 2012).

An enormous empirical studies emerged to examine the impact of institution on economic performance (Jalilian et al., 2003; Rodrik, Subramanian \& Trebbi, 2004; Acemoglu et al., 2005; Habtamu, 2008; Fabro \& Aixalá, 2009; Batuo \& Fabro, 2009; Commander \& Nikoloski, 2010; Osman, Alexiou \& Tsaliki, 2011; Fayissa \& Nsiah, 2013; Kilishi, Mobolaji \& Yaru, 2013; Han, Khan \& Zhuang, 2014; Iqbal \& Daly, 2014; Nawaz, 2015; Effiong, 2015; Valipoor \& Bakke, 2016).Most of the these studies establishes positive relationship between institution and economic performance. In addition, the above studies conclude that institutions are the fundamental cause of economic growth and development differences across countries and hence poor quality of institution is the root cause of economic problem of third world countries. Thus, the poor economic performance of the SSA has been linked to intuitional quality. However, studies are ambiguous on the channel through which institutional quality affect economic performance due the existence of various measure institutional qualities and the methodological applied. Most of the existing literatures assume homogenous relationships across the country included in the analysis which is not always the case(Chang, 2011; Eicher \& Leukert, 2006; Luiz, 2009).In addition, Most of the above studies incorporate larger number of countries in their analysis, hence failed to address the unexpected shocks that are specific to one country and one period.

To this end, the main objective of this study is to investigate institutional quality and economic performance relationships in 14 selected Eastern Africa countries by employing fixed effect and SYS-GMM over 2005-20016 periods.

\section{LITERATURE REVIEW}

The question of what makes societies economically successful remains the concern of many social scientists for a long periods. Especially, economists have developed different theoretical framework to explain the cause of cross-country difference in economic growth and development. Until 1980s, human capital, physical capital, technology advancement remain the driving factors behind economic growth and development of a country. Post 1980s, the new institutional economics integrated the theory of institution into the mainstream economic (Sardadvar, 2011). The Institutional economics stresses the crucial role of institutions in economic performance of a Country. It provides a framework for understanding the interaction of government structures, firm organization, and individual decisions, emphasizing transaction costs as a central component of economic activity (Wajda, 2015).

The most widely used definition of institutions which based on Douglas North framework is that the formal rules (a constitution, laws and regulations, a political system, property rights, etc.) and informal rules (a system of values and beliefs, customs, ideas, social norms, etc.) that govern the behavior of individuals and organizations (Hodgson, 2006). On the other hand, Vitola \& Senfelde (2015) define institutions as socially approved behavior models that restrict the rationality of an individual and constrain or encourage specific behavior, and assume that high quality institutions encourage an efficient use of limited production resources in order to fulfill the needs of society. 
Today, Empirical literatures are exponentially increasing in searching for what explain larger difference in property across a country. Jalilian, Kirkpatrick \& Parker (2003) explored the impact of the quality of regulatory governance on economic growth .Using the World wide governance Indicators(WGI) and applying the OLS and fixed effect estimation techniques ; regulatory quality found to have positive impact on economic growth of developing countries. Habtamu (2008), using System GMM over 1996-2005 for 35 Sub-Saharan Africa (SSA), found that institutional qualities such as Rule of law, government effectiveness, regulatory quality, political instability, and voice and accountability were found to influence the growth of SSA, while control over corruption has no relation to growth in the region. Fabro \& Aixalá (2009), using dynamic panel and Instrumental variable estimation techniques for 145 rich and poor countries, found that for the total sample of countries institutional arrangement is a fundamental factor for explaining the level of economic development. However, when countries divided up based on income level, they found no evidence that institutional qualities are important in poor countries.

Osman, Alexiou \& Tsalik (2011) examined the link between institutional quality and economic performance in 27 Sub-Saharan Africa (SSA) countries during the period 1984-2003.Using ICRG index of institutional quality and static and dynamic panel estimation techniques, the study found that institutional variables assume a key role in the process of economic development whereas the control variables display a limited effect. Kilishi, Mobolaji, Yaru, (2013), using the World wide governance data over 1996-2010 for 36 SSA and employing System Generalized Method of Moment (GMM) estimators, found that institution really matter for Sub-Saharan Africa's economic performance, among which regulatory quality appeared to be the most important. Fayisa \& Nsiah (2013), using a panel of data for 39 Sub-Sahara African countries and employing a dynamic and static panel data destination, found that good quality of institutions has a positive and significant impact on growth.

Most of these studies establish positive relationship between institution and economic performance. In addition, the above studies conclude that institutions are the fundamental cause of economic growth and development differences across countries and hence poor quality of institution is the root cause of economic problem of third world countries. Thus, the poor economic performance of the SSA has been linked to intuitional quality. However, studies are ambiguous on the channel through which institutional quality affect economic due the existence of various measures institutional qualities and the methodological applied. Most of the existing literatures assume homogenous relationships across the country included in the analysis which is not always the case (Eicher \& Leukert, 2006; Luiz, 2009; Chang, 2011).In addition, Most of the above studies incorporate larger number of countries in their analysis, hence failed to address the unexpected shocks that are specific to one country and over period. Docquier (2014) stated that instead of comparing a larger number of countries having heterogeneous characteristics, it might be interesting to focus on a smaller sample of counties that are likely similar and experienced institutions change at different period. To this extent, this study selected the Eastern Africa countries.

The Eastern Africa Countries, especially the Horn Africa are known for the most conflict area in the World. For instance, today countries such as Ethiopia and Kenya are experiencing the fasted growing economy in the area. Evidence shows that, Despite increasing economic growth in the region, on average than other regions, institutional quality in East African is weakening (UNODC, 2013; Solomon, 2014).Thus, there is 
need to investigate the extent to which the institutional quality affect the economic performance of countries in this region.

\section{METHODS}

\section{Data type and source}

This study has used Panel dataset of 14 selected Eastern Africa countries such as the East African countries investigated in this study are; Burundi, Comoros, Djibouti, Ethiopia, Kenya, Madagascar, Malawi, Mozambique, Mauritius, Rwanda, Tanzania, Uganda, Zambia and Zimbabwe, which is a 12 year records between the years of 20052016 period. The data are obtained from different sources, such as Worldwide Governance Indicators (WGI), Center for Systematic peace (CSP), World Development Indicators (WDI), IMF and UNCATD databases.

Data on quality of economic institutions indicators has been obtained from WGI database which produced by Kaufmann et al. (2011) and compiled at the World Bank annually. These indicators are based public opinion and perception-based surveys of various governance measures from investors, consulting firms, non-government organizations, governments, and multilateral agencies; and classified into six clusters. According to Kaufmann, Kraay \& Mastruzzi (2010), these indicators are conceptually defined as follows:

Government effectiveness (GEE): It captures perceptions of the quality of public services, the quality of the civil service and the degree of its independence from political pressures, the quality of policy formulation and implementation, and the credibility of the government's commitment to such policies.

Regulatory quality (RQE): It captures perceptions of the ability of the government to formulate and implement sound policies and regulations that permit and promote private sector development.

Rule of law (RLE): It captures perceptions of the extent to which agents have confidence in and abide by the rules of society, and in particular the quality of contract enforcement, property rights, the police, and the courts, as well as the likelihood of crime and violence.

Control of corruption (CCE): It captures perceptions of the extent to which public power is exercised for private gain, including both petty and grand forms of corruption, as well as the "capture" of the state by elites and private interests.

To measure quality of Political institution; the study used polity 2 variable from polity4 project of CSP.Polity2 is a scale measurement ranging from ranges from +10 (strongly democratic) to-10 (strongly autocratic), which is computed by subtracting the indicator of Autocracy score from the indicator of Democracy score (Marshal, Gurr, \& Jaggers, 2016).

GDP per capita at 2010 \$US constant price has used as dependent variable in the analysis. Data on GDP per capita has been obtained from WDI. In addition, data on annual population growth rate, total investment and trade openness sourced from World Development Indicators, IMF and UNCATD respectively.

\section{Econometrics model specification}

In order to explore the impact institutional quality of economic performance Eastern African (EA), the study employed panel data analysis approach. Following the study specifies the log linear economic growth model augmented with institutional variables as the following:

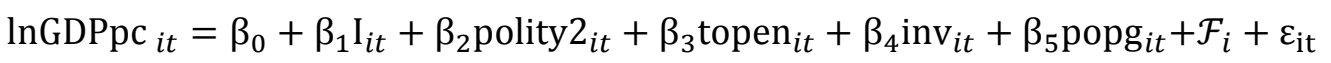


Where,

$\mathrm{i}=1,2 \ldots, \mathrm{N}$ is the number of countries; $\mathrm{t}=1,2, \ldots, \mathrm{T}$ is time period, a $\mathrm{K} 1$ vector which is slopes of independent variables $i$, is the unobserved heterogeneity and is the error.is logarithm of level of GDP per capita, "I" is the indicators of quality of economic institutions (such as, CCE, GEE, RQE and RLE), topen is trade openness which is the sum of exports and imports of goods and services measured as a share of gross domestic product,polity 2 is the proxy measure of quality of political institution, "inv" is Investment as a percentage of GDP is calculated at market prices, "popg" represents annual population growth rate.

With the equation of the model (1), due high correlation between the four measures of quality of economic institutions it is impossible to regress all of them at the same time. . For this reason, the method of principal component analysis is used to deal with the possible multi-collinearity problem. Principal component analysis (PCA) is a statistical technique used for dimension reduction.

Depending on this problem, the study has been designed on two analytical methods. First, the composite indicator for all quality of economic institution has computed by PCA. In this manner, the four measures of quality of economic institutions namely: CCE, GEE, RQE and RLE were aggregated as one indicator of institutional quality. The Second method of analysis applies disaggregated analysis. In this case, the impact of each of the individual indicators on economic performance examined separately.

\section{Estimation techniques}

The most popular method to estimate equation (1) is the static panel estimation method. It commonly known that Static panel data estimation involves the fixed effect (FE) and random effect (RE) estimation. This study has chosen fixed effect estimation over random effect due to its advantage in controlling of unobserved county and time fixed effect. The random effect assume that unobserved country fixed effect are uncorrelated with error term which impossible in this study. For instance geography, culture, history and distance to equator and many other fixed factors exists to be correlated with institutional variables which cannot be controlled in random effect.

In fact, the FE employed in this involves the method of LSDV which take into accountant country and time fixed effect. This technique is sensitive to heteroscedasticity problem. The Brush pagan test is used to test this problem which has the null hypothesis of there is a constant variance. The larger probability value is required to accept to these hypotheses. When this null hypotheses rejected the Feasible Generalized Least squares (FGLS) is employed in order to improve the efficiency of the FE. With FGLS we can estimate the Fixed effect regression model of equations (3.34) and (3.4) under the assumptions of homoscedastic and no autocorrelation. In addition, FGLS allows estimation in the presence of first order autocorrelation, AR (1), within panels and cross-sectional correlation and heteroscedasticity across panels (Greene, 2012).

However, economic relationships usually involve dynamic adjustment processes and dataset are panel data with small time period there has been often problem of inference, such as sample bias in coefficients and hypothesis tests. Therefore, neither FE nor the RE is unbiased and consistent. Thus, under such problem the appropriate model is dynamic panel data modeling. Such model is appropriate when the outcome variable of interests depend past realization. In this approach equation (1) can be specified as in the following: 


$$
\begin{aligned}
\operatorname{lnGDPc} c_{i t}= & \beta_{0}+\beta_{1} \operatorname{lnGDPc}_{\mathrm{it}-1}+\beta_{2} \mathrm{I}_{i t}+\beta_{3} \text { polity }_{i t}+\beta_{4} \text { popg }_{i t}+\beta_{5} \text { topen }_{\mathrm{it}}+ \\
& \beta_{6} i n v_{\mathrm{it}}+\mathcal{F}_{\mathrm{i}}+\varepsilon_{\mathrm{it}}
\end{aligned}
$$

The popular method to estimate equation (2) is called Generalized Method of Moments (GMM). It is the extension of Instrumental Variable (IV) approach in order to form the instrument for endogenous variables from its own past lag value. The most important reason of choosing GMM estimation techniques over IV estimation is that it's not appropriate techniques when there is more instrument than endogenous variables, which happen in the case of these study variables of institutional quality. In addition, with GMM estimation there no needs to be worry about homoscedastic and stationary (Hansen, 1982).

In fact, GMM estimation has two types: the first difference GMM (Diff-GMM) and System GMM (SYS-GMM). The Diff-GMM is estimation technique which apply first differencing to the original model and use moment condition to generate internal instrument for variable that are endogenous (Arellano \& Bond (1991).This approach does not provide good estimator under heteroscedasticity and for time invariant repressors. To address this problem, Arellano \& Bover (1995) as well as Blundell \& Bond (1998) proposed the SYS-GMM as an alternative. Because of this reason SYS_GMM estimation has been employed in this study. The System GMM estimators involve two step processes. In steps one the System GMM not robust. Therefore, the "two step" SYS- GMM should be performed in order to improve the efficiency of the estimation result.

In order to generate internal instrument, the SYS-GMM form two systems of equations: one equation in level form and one other in differenced form. Using the moment condition, it generates two kinds of instruments; one group of instrument the lagged level and the other group are the first differenced instruments. Finally, equations in level forms are instrumented with differenced instruments while equations in first difference are instrumented with instrument in lagged level (Roadman, 2009). In order to be valid

Therefore, the validity of SYS-GMM estimation results depends on the validity of these instruments. These instruments should not be greater than number of observations and strictly exogenous. The formal test statistics for this is called Hansen J-statistics. This test has two null hypotheses:

$\mathrm{H}_{01}$ : Instruments as group are valid

$\mathrm{H}_{02}$ : Instruments are valid exclusively

Therefore, the higher the P-value of the Hansen J-statistics is better to accept this hypothesis

In addition, the estimated result of SYS-GMM is consistent if there is no evidence of significant second order serial autocorrelation. The Arellano and Bond (AR) Test have been used to test the null hypothesis of no autocorrelations. Similarly, the higher the P-value of AR (2) is better to accept this hypothesis to retail this hypothesis.

\section{RESULTS AND DISCUSSION}

As discussed in methodology section, the result of this study has been based the Fixed Effect and System GMM estimation techniques. The fixed effect has been employed to deal with heterogeneity among the individual country and the system GMM estimation is to deal with the endogeneity problem. Since the Fixed estimation results suffer from heteroscedasticity problem, the method of Feasible Generalized Least square estimation (FGLS) technique was used. Through this study, robust estimation result of fixed effect estimation mean that FGLS. 
Table 1 shows the diagnostics test results for SYS-GMM .In this study, five models were estimated as indicated table 2-6 below and the diagnostics tests for these results are presented in table 1 through column 2- 6. As indicate clearly in the table the number of instrument in each regression is smaller than the number of observations $(\mathrm{N}=153)$, which pretty what is desirable. On the other hand, the minimum of 1 and maximum of 4 lag values was imposed on the predetermined variable, since one period lag of predetermined variables are not assumed to be correlated with current shocks. For this study, one period lagged dependent variable (l. $\operatorname{lnGDPpc}$ ) is treated as predetermined variable meaning that it's not strictly endogenous. In addition, The minimum and maximum lag limit imposed on endogenous variables, that is all independent variables except lagged value of GDPpc, is 2 which can be written as lag (2 2) (Roadman, 2009).

Table1. Model diagnostic test results for system GMM

\begin{tabular}{lrrrrr}
\hline \multicolumn{1}{c}{ Evaluation criteria } & Table 2 & Table 3 & Table 4 & Table 5 & Table 6 \\
\hline Observations & 153 & 153 & 153 & 153 & 153 \\
Number of Instruments & 16 & 14 & 16 & 14 & 42 \\
Lag limit (min/max) & $(1 / 4)$ & $(1 / 2)$ & $(1 / 4)$ & $(1 / 2)$ & $(1 / 2)$ \\
Second order Autocorrelation( AR2) :p-value & 0.422 & 0.095 & 0.417 & 0.065 & 0.544 \\
Hansen test of Overid. restrictions: p-vale & 0.939 & 0.605 & 0.939 & 0.730 & 1.00
\end{tabular}

Testing the validity of instruments in subsets of equations

GMM(endogenous var.) type instruments

$\begin{array}{llllll}\text { Hansen test excluding group: } p \text {-value } & 0.986 & 0.607 & 0.986 & 0.744 & 1.00\end{array}$

GMM(predetermined var.) type instrument

$\begin{array}{lllllll}\text { Hansen test excluding group: } & \text { p-value } & 0.971 & 0.305 & 0.976 & 0.318 & 1.00\end{array}$

Source: Own estimate using Stata 13.

Note: The term in parenthesis "( $\mathrm{min} / \mathrm{max})$ " used with lag limit means minimum and maximum lag imposed on variables used as instrument, here on predetermined variables

Moreover, as clearly depicted in the table1there is no second order autocorrelation. The p-value for Arellano - Bond test -AR (2) is 1 which cannot reject the null hypothesis of no autocorrelation at 0.05 levels. Furthermore, Hansen test for instrument over identification and instrument in subset of equation are valid and the null hypotheses of instruments are valid cannot be rejected at $1 \%$ convectional level.

Table 2 shows the result of the aggregate impact of institutional quality on economic performance of the Eastern African. From the table it is clear that the aggregate indicator of quality of economic (Einst) has positive significant on economic performance at $1 \%$ convectional level under the robust FE estimation. The result is consistent under the SYS-GMM at 5\% level. Using the SSY-GMM results, we can infer that one unit increase in institutional quality would leads to $3.6 \%$ increase economic performance. In addition, the result implies that improvement in quality of economic institutions would have huge contribution for economic welfare and country with better quality of institution would have better economic performance. In fact, this finding is in accordance with (Kilishi, Mobolaji \& Yaru, 201; Fayisa \& Nsiah, 2013; Batuo \& Fabro, 2009). On the other hand, the robust estimation result of fixed effect shows that Polity2 has positive relationships with GDPpc per capita. The result implies that each individual country has its own and time fixed effect that affects quality of economic institution which in turn impacted on economic performance. However, the results of SYS-GMM indicate that polity2 has insignificant impact on economic performance. This result does not mean that polity2is not important, rather the deteriorations quality of political institution. This result is in line with Commander \& Nikoloski (2010). 
The other control variable, total investment (inv) has positive country and time effect on economic performance. However, after controlling for endogeneity, investment has insignificant impact on GDP per capita. This shows that keeping institutional constant, the impact of investment on economic performance is limited in Eastern African. PO Finally, the SYS-GMM results indicate that one period lag of GDP per capita (l. $\operatorname{lnGDPpc}$ ) has positive significant effect on economic performance. The result implies that Eastern Africa Economic performance depends on its own past performance than other factors.

Table 2.The impact of aggregate quality of economic institutions on economic performance

\begin{tabular}{|c|c|c|c|c|c|}
\hline \multicolumn{6}{|c|}{ Dependent variable is GDP per capita (InGDPpc) } \\
\hline \multirow{2}{*}{$\begin{array}{c}\text { Independent } \\
\text { variables }\end{array}$} & \multicolumn{2}{|c|}{$\mathrm{FE}$} & \multicolumn{2}{|c|}{ FGLS } & \multirow[t]{2}{*}{ SYS-GMM } \\
\hline & $\mathrm{C}$ & $\mathrm{C} \& \mathrm{~T}$ & $\mathrm{C}$ & $\mathrm{C} \& \mathrm{~T}$ & \\
\hline Einst & $\begin{array}{l}0.140 * * * \\
(0.0348)\end{array}$ & $\begin{array}{l}0.124 * * * \\
(0.0228)\end{array}$ & $\begin{array}{l}0.140 * * * \\
(0.0327)\end{array}$ & $\begin{array}{l}0.124 * * * \\
(0.0207)\end{array}$ & $\begin{array}{l}0.036 * * \\
(0.015)\end{array}$ \\
\hline polity2 & $\begin{array}{l}0.0197 * * * \\
(0.00699)\end{array}$ & $\begin{array}{r}0.00740 \\
(0.00466)\end{array}$ & $\begin{array}{c}0.0197 * * * \\
(0.00658)\end{array}$ & $\begin{array}{c}0.00740 * \\
(0.00422)\end{array}$ & $\begin{array}{r}0.006 \\
(0.008)\end{array}$ \\
\hline Topen & $\begin{array}{r}0.00000 \\
(0.000851)\end{array}$ & $\begin{array}{r}-0.00013 \\
(0.000601)\end{array}$ & $\begin{array}{r}0.00000 \\
(0.000801)\end{array}$ & $\begin{array}{r}-0.00013 \\
(0.000544)\end{array}$ & $\begin{array}{r}0.00000 \\
(0.001)\end{array}$ \\
\hline Inv & $\begin{array}{l}0.00560 * * * \\
(0.00126)\end{array}$ & $\begin{array}{c}0.00284 * * * \\
(0.000842)\end{array}$ & $\begin{array}{l}0.00560 * * * \\
(0.00119)\end{array}$ & $\begin{array}{c}0.00284 * * * \\
(0.000763)\end{array}$ & $\begin{array}{r}0.000 \\
(0.001)\end{array}$ \\
\hline Popg & $\begin{array}{l}-0.168 * * \\
(0.0724)\end{array}$ & $\begin{array}{r}-0.0696 \\
(0.0485)\end{array}$ & $\begin{array}{l}-0.168 * * \\
(0.0681)\end{array}$ & $\begin{array}{r}-0.0696 \\
(0.0439)\end{array}$ & $\begin{array}{l}-0.069 * \\
(0.036)\end{array}$ \\
\hline L.InGDPpc & & & & & $\begin{array}{l}0.894 * * * \\
(0.047)\end{array}$ \\
\hline Constant & $\begin{array}{l}7.113^{* * * *} \\
(0.228)\end{array}$ & $\begin{array}{l}6.756^{* * * *} \\
(0.152)\end{array}$ & $\begin{array}{l}7.113 * * * \\
(0.214)\end{array}$ & $\begin{array}{l}6.756^{* * * *} \\
(0.137)\end{array}$ & $\begin{array}{l}0.942 * * \\
(0.417)\end{array}$ \\
\hline $\begin{array}{l}\text { Observations } \\
\text { R-squared }\end{array}$ & $\begin{array}{r}167 \\
0.979\end{array}$ & $\begin{array}{r}167 \\
0.992\end{array}$ & 167 & 167 & 153 \\
\hline Number of Cou & tries & & 14 & 14 & 14 \\
\hline
\end{tabular}

Source: Own estimates using Stata 13.

Note: Standard errors in parentheses, $* * * p<0.01$ means significant at $1 \%, * * p<0.05$ means significant at $5 \%, * p<0.1$ means significant at $10 \%$ level. Whereas, $C$ indicate country fixed effect and $C \& T$ indicate country and Time effect.

Table 3 shows that the estimated results of control of corruption (CCE) on Eastern African economic performance. The result indicates that CCE has positive effect on GDP per capita (GDPpc).The result implies that this positive impact depend on country and time fixed effect. This confirm with (Batuo \& Fabro, 2009; Han, Khan \& Zhuang, 2014; Valipoor \& Bakke, 2016) which stated that in country where control of corruption is high their economic growth and development better. Similar to in case of Einst, the robust estimation result of fixed effect shows that Polity2 has positive relationships with GDPpc per capita, when CCE and other variables kept constant. The result implies that each individual country has its own and time fixed effect that affects quality of economic institution which in turn impacted on economic performance. However, the results of SYS-GMM indicate that polity2 has insignificant impact on economic performance. This result does not mean that quality of political institution not important, rather the deteriorations quality of political institution. This result is in line with Commander \& Nikoloski (2010). 
Table 3. Estimated impact of Control of corruption on economic performance

\begin{tabular}{|c|c|c|c|c|c|}
\hline \multicolumn{6}{|c|}{ Dependent variable is GDP per capita (lnGDPpc) } \\
\hline \multirow{2}{*}{$\begin{array}{c}\text { Independent } \\
\text { Variables } \\
\end{array}$} & \multicolumn{2}{|c|}{$\mathrm{FE}$} & \multicolumn{2}{|c|}{ FGLS } & \multirow[t]{2}{*}{ SYS-GMM } \\
\hline & $\mathrm{C}$ & $\mathrm{C} \& \mathrm{~T}$ & $\mathrm{C}$ & $\mathrm{C} \& \mathrm{~T}$ & \\
\hline $\mathrm{CCE}$ & $\begin{array}{l}0.159 * * * \\
(0.0575)\end{array}$ & $\begin{array}{l}0.212 * * * \\
(0.0363)\end{array}$ & $\begin{array}{l}0.159 * * * \\
(0.0541)\end{array}$ & $\begin{array}{l}0.159 * * * \\
(0.0541)\end{array}$ & $\begin{array}{c}0.054^{*} \\
(0.030)\end{array}$ \\
\hline polity2 & $\begin{array}{l}0.0245 * * * \\
(0.00725)\end{array}$ & $\begin{array}{c}0.0119 * * \\
(0.00462)\end{array}$ & $\begin{array}{l}0.0245 * * * \\
(0.00683)\end{array}$ & $\begin{array}{l}0.0245 * * * \\
(0.00683)\end{array}$ & $\begin{array}{r}0.001 \\
(0.003)\end{array}$ \\
\hline Topen & $\begin{array}{r}-0.00009 \\
(0.000875)\end{array}$ & $\begin{array}{r}-0.00020 \\
(0.000591)\end{array}$ & $\begin{array}{r}-0.00009 \\
(0.000824)\end{array}$ & $\begin{array}{r}-0.00009 \\
(0.000824)\end{array}$ & $\begin{array}{l}0.001 * * \\
(0.001)\end{array}$ \\
\hline Inv & $\begin{array}{l}0.00551 * * * \\
(0.00131)\end{array}$ & $\begin{array}{l}0.00228 * * * \\
(0.000844)\end{array}$ & $\begin{array}{l}0.00551 * * * \\
(0.00123)\end{array}$ & $\begin{array}{l}0.00551 * * * \\
(0.00123)\end{array}$ & $\begin{array}{r}0.001 \\
(0.001)\end{array}$ \\
\hline Popg & $\begin{array}{l}-0.183^{* * *} \\
(0.0769)\end{array}$ & $\begin{array}{l}-0.103^{* *} \\
(0.0489)\end{array}$ & $\begin{array}{l}-0.183^{* *} \\
(0.0724)\end{array}$ & $\begin{array}{c}-0.183^{* *} \\
(0.0724)\end{array}$ & $\begin{array}{r}-0.038 \\
(0.043)\end{array}$ \\
\hline L.lnGDPpc & & & & & $\begin{array}{l}0.977 * * * \\
(0.024)\end{array}$ \\
\hline Constant & $\begin{array}{l}7.214 * * * \\
(0.261)\end{array}$ & $\begin{array}{l}6.992 * * * \\
(0.165)\end{array}$ & $\begin{array}{l}7.214 * * * \\
(0.246)\end{array}$ & $\begin{array}{l}7.214 * * * \\
(0.246)\end{array}$ & $\begin{array}{r}0.222 \\
(0.230) \\
\end{array}$ \\
\hline $\begin{array}{l}\text { Observations } \\
\text { R-squared }\end{array}$ & $\begin{array}{r}167 \\
0.978\end{array}$ & $\begin{array}{r}167 \\
0.992\end{array}$ & 167 & 167 & 153 \\
\hline Number of $\mathrm{Col}$ & tries & & 14 & 14 & 14 \\
\hline
\end{tabular}

Source: Own Estimates using Stata 13.

Note: Standard errors in parentheses, $* * * p<0.01$ means significant at $1 \%$, ** $p<0.05$ means significant at $5 \%$, * $p<0.1$ means significant at $10 \%$ level. Whereas, $C$ indicate country fixed effect and $C \& T$ indicate country \& Time effect.

The control variables; investment (inv), and population growth (popg) has positive and negative significant country and time fixed effect respectively .But, the SYS-GMM result revealed that the standard economic variables has no relation with the Eastern African economic performance. This confirms with (Fayisa \& Nsiah, 2013; Kilishi, Mobolaji \& Yaru, 2013) which argued that standard economic variable has limited impact on economic performance once institution s are control for. Finally, the results of SYS-GMM indicate that trade openness and lagged value of GDP per capita has positive significant impact on economic performance. But, the magnitude of lagged value of GDP per capita is high indicating that economic performance depends on it past performance than the other factors.

Table4shows the estimated impact of government effectiveness (GEE) on economic performance of the Eastern Africa. The robust estimation of FE indicates that GEE has positive impact on GDP per capita (1.lnGDPpc) at 5\% under SYS-GMM. The possible impact of GEE implies that each country has unique and time effect government effectiveness. This finding also confirm with the hypothesis of this research and the previous studies (Development, 2009; Effiong, 2015; Habtamu, 2008; (Fayisa \& Nsiah, 2013; Kilishi, Mobolaji \& Yaru, 2013).Therefore, using the SYS-GMM estimation we can infer that one unit improvement in government effectiveness would leads to $6.3 \%$ increase in GDP per capita. Keeping GEE and other variables at constant, polity have positive impact on GDP per capita under the fixed effect estimation. However, this results loss its consistency after dealing with endogeniety which show that deterioration of quality of political institutions in the Eastern Africa. This result confirms with(Commander \& Nikoloski, n.d.). 
Table 4. Estimated impact of government effectiveness on economic performance

\begin{tabular}{|c|c|c|c|c|c|}
\hline \multicolumn{6}{|c|}{ Dependent Variable is GDP per capita(InGDPpc) } \\
\hline \multirow{2}{*}{$\begin{array}{c}\text { Independent } \\
\text { Variables }\end{array}$} & \multicolumn{2}{|c|}{ FE } & \multicolumn{2}{|c|}{ FGLS } & \multirow[t]{2}{*}{ SYS-DGMM } \\
\hline & $\mathrm{C}$ & $\mathrm{C} \& \mathrm{~T}$ & $\mathrm{C}$ & $\mathrm{C} \& \mathrm{~T}$ & \\
\hline GEE & $\begin{array}{l}0.239 \text { *** } \\
(0.0592)\end{array}$ & $\begin{array}{l}0.211 \text { *** } \\
(0.0389)\end{array}$ & $\begin{array}{l}0.239 * * * \\
(0.0557)\end{array}$ & $\begin{array}{l}0.211 \text { *** } \\
(0.0352)\end{array}$ & $\begin{array}{l}0.063^{* *} \\
(0.026)\end{array}$ \\
\hline polity 2 & $\begin{array}{l}0.0197 * * * \\
(0.00699)\end{array}$ & $\begin{array}{r}0.00740 \\
(0.00466)\end{array}$ & $\begin{array}{l}0.0197 * * * \\
(0.00658)\end{array}$ & $\begin{array}{c}0.00740^{*} \\
(0.00422)\end{array}$ & $\begin{array}{r}0.005 \\
(0.008)\end{array}$ \\
\hline Topen & $\begin{array}{r}0.000001 \\
(0.000851)\end{array}$ & $\begin{array}{r}-0.000131 \\
(0.000601)\end{array}$ & $\begin{array}{r}0.000001 \\
(0.000801)\end{array}$ & $\begin{array}{r}-0.000131 \\
(0.000544)\end{array}$ & $\begin{array}{r}0.000000 \\
(0.001)\end{array}$ \\
\hline Inv & $\begin{array}{l}0.00560 * * * \\
(0.00126)\end{array}$ & $\begin{array}{l}0.00284 * * * \\
(0.000842)\end{array}$ & $\begin{array}{l}0.00560 * * * \\
(0.00119)\end{array}$ & $\begin{array}{c}0.00284 * * * \\
(0.000763)\end{array}$ & $\begin{array}{r}0.000 \\
(0.001)\end{array}$ \\
\hline Popg & $\begin{array}{l}-0.168^{* *} \\
(0.0724)\end{array}$ & $\begin{array}{r}-0.0696 \\
(0.0485)\end{array}$ & $\begin{array}{l}-0.168^{* *} \\
(0.0681)\end{array}$ & $\begin{array}{r}-0.0696 \\
(0.0439)\end{array}$ & $\begin{array}{l}-0.067^{*} \\
(0.036)\end{array}$ \\
\hline \multicolumn{3}{|l|}{ L.lnGDPpc } & & & $\begin{array}{l}0.896^{* * *} \\
(0.048)\end{array}$ \\
\hline Constant & $\begin{array}{l}7.272 * * * \\
(0.242)\end{array}$ & $\begin{array}{l}6.897 * * * \\
(0.161)\end{array}$ & $\begin{array}{l}7.272 * * * \\
(0.228)\end{array}$ & $\begin{array}{l}6.897 * * * \\
(0.146)\end{array}$ & $\begin{array}{l}0.962 * * \\
(0.415)\end{array}$ \\
\hline $\begin{array}{l}\text { Observations } \\
\text { R-squared }\end{array}$ & $\begin{array}{r}167 \\
0.979\end{array}$ & $\begin{array}{r}167 \\
0.992\end{array}$ & 167 & 167 & 153 \\
\hline \multicolumn{3}{|c|}{ Number of Countries } & 14 & 14 & 14 \\
\hline
\end{tabular}

Source: Own estimates using Stata 13.

Note: Standard errors in parentheses, *** $p<0.01$ means significant at $1 \%, * * p<0.05$ means significant at $5 \%, * p<0.1$ means significant at $10 \%$ level. Whereas, $C$ indicate country fixed effect and $C \& T$ indicate country \& Time effect.

The standard economic variables: investment and annual pollution growth rate (popg), which are used as control variables has positive and negative significant impact on the region economic performance under the FE robust estimation at $1 \%$ and 5\% level respectively. After dealing with endogeneity problem, the negative impact of pogg is inconsistent and inv has negative impact at $10 \%$ which is almost negligible. Finally, one period lag of GDP per capita has significant on current economic performance of the Eastern African. The SYS-GMM estimation result of table 4.8 shows that 1 . lnGDPpc statistically significant at $1 \%$ level, with positive sing of 0.896 . This indicates that the Eastern African Economic Performance depends on its past performance than GEE and other factors.

Table 5 shows the impact of regulatory quality (RQE) on Easter African economic performance. The robust estimation result of FE indicates that RQE has significant impact on GDP per capita at $1 \%$ level, which implies that RQE depends on country fixed effect. However, the result was not consistent under the SYS-GMM implying the absence of RQE relation to economic performance in Eastern Africa. This result confirms with WB (2002).

In addition, robust estimation result of FE in the table 5 show that Polity 2 and investment (inv) has positive impact on the Eastern African economic performance at $1 \%$ level. However, this result is inconsistent when endogeneity problem was dealt with. The result indicates the deterioration of political institutions and weak investment environment in the Eastern African. Annual population growth has negative significant impact on GDP per capita at 5\% and 10\% convectional level under the FGLS and SYSGMM respectively. The result implies that annual population growth rate depend on country fixed effect and as population grow decrease by one unit, economic performance would increase by $3.9 \%$. The result of SYS-GMM shows that Trade 
openness (Topen) and lagged value of GDP per capita (L.lnGDPpc) has positive significant impact on the Eastern African Economic performance at $10 \%$ and $1 \%$ convection level. However, the larger significance level of Topen shows that trade openness has negligible impact on the region economic performance. The positive impact of lagged value of GDP per capita shows that the performance of the region economies depends on its past performance.

Table 5.The effect of regulatory quality on economic performance

\begin{tabular}{|c|c|c|c|c|c|}
\hline \multicolumn{6}{|c|}{ Dependent variable is GDP per capita } \\
\hline \multirow{2}{*}{$\begin{array}{c}\text { Independent } \\
\text { Variables } \\
\end{array}$} & \multicolumn{2}{|c|}{$\mathrm{FE}$} & \multicolumn{2}{|c|}{ FGLS } & \multirow[t]{2}{*}{ SYS-GMM } \\
\hline & $\mathrm{C}$ & C\&T & $\mathrm{C}$ & $\mathrm{C} \& \mathrm{~T}$ & \\
\hline \multirow[t]{2}{*}{ RQE } & $0.236 * * *$ & 0.0599 & $0.236 * * *$ & 0.0599 & 0.027 \\
\hline & $(0.0535)$ & $(0.0411)$ & $(0.0503)$ & $(0.0373)$ & $(0.037)$ \\
\hline \multirow[t]{2}{*}{ polity2 } & $0.0215^{* * *}$ & $0.00927 *$ & $0.0215 * * *$ & $0.00927 * *$ & -0.000 \\
\hline & $(0.00692)$ & $(0.00510)$ & $(0.00651)$ & $(0.00462)$ & $(0.002)$ \\
\hline \multirow[t]{2}{*}{ Topen } & 0.000067 & -0.000449 & 0.000067 & -0.000449 & $0.001 *$ \\
\hline & $(0.000844)$ & $(0.000660)$ & $(0.000795)$ & $(0.000598)$ & $(0.001)$ \\
\hline \multirow[t]{2}{*}{ Inv } & $0.00488 * * *$ & $0.00303 * * *$ & $0.00488 * * *$ & $0.00303 * * *$ & 0.001 \\
\hline & $(0.00128)$ & $(0.000929)$ & $(0.00120)$ & $(0.000842)$ & $(0.001)$ \\
\hline \multirow[t]{2}{*}{ Popg } & $-0.156 * *$ & -0.0419 & $-0.156 * *$ & -0.0419 & $-0.039 *$ \\
\hline & $(0.0712)$ & $(0.0530)$ & $(0.0670)$ & $(0.0480)$ & $(0.018)$ \\
\hline \multirow[t]{2}{*}{ L.InGDPpc } & & & & & $0.958 * * *$ \\
\hline & & & & & $(0.024)$ \\
\hline \multirow[t]{2}{*}{ Constant } & $7.198 * * *$ & $6.619 * * *$ & $7.198 * * *$ & $6.619 * * *$ & $0.354 *$ \\
\hline & $(0.230)$ & $(0.173)$ & $(0.217)$ & $(0.157)$ & $(0.188)$ \\
\hline Observations & 167 & 167 & 167 & 167 & 153 \\
\hline R-squared & 0.980 & 0.991 & & & \\
\hline Number of countries & & & 14 & 14 & 14 \\
\hline
\end{tabular}

Source: Own estimates using Stata 13.

Note: Standard errors in parentheses the Asterisk; *** $p<0.01$ means significant at $1 \%$, ** $p<0.05$ means significant at 5\%, * $p<0.1$ means significant at $10 \%$ level. Whereas, C indicate country fixed effect and $C \&$ indicate country \& Time effect.

Table 6 shows the impact of rule of law (RLE) on economic performance of the Eastern African. The robust FE estimation result shows that RLE has positive significant impact on GDP per capita. This positive impact depends on the country and time fixed effect. But, the SYS-GMM indicated that the impact of RLE on economic performance of the region is negative at $1 \%$ convectional level. This finding contradicts with what expected in this study, but in line with (Kaufman \& kraay, 2002) which stated that institutional development which depend on per capita income lead to a weak and even negative economic performance.

On the other hand, table 6 shows that polity2 has only significant impact on GDP per capita under the country fixed effect model, which is not consistent under the SYSGMM. This result indicates the deterioration of quality of political system in Eastern Africa. In addition, Trade openness (Topen), which used control variable for RLE, has no significant impact on economic performance under the fixed effect. But after controlling for endogeneity, it turns out to be significant at $1 \%$ convection level. This result implies that the impact of Topen depend well-functioning rule of law. Moreover, Investment and annual population growth rate are the other variables that are used as control variable. These two variables have significant impact on economic performance at $1 \%$ and $10 \%$ convectional level under the fixed effect estimation. But, the result is 
not consistent after dealing with the edongeneity problem. Finally, lagged value of GDP per capital (1. lnGDPpc) has positive impact on economic performance at $1 \%$ conventional level which implies that the performance of the region economies region depend its past performance than institutional quality and other factors.

Table 6. Estimated impact of rule of law on economic performance

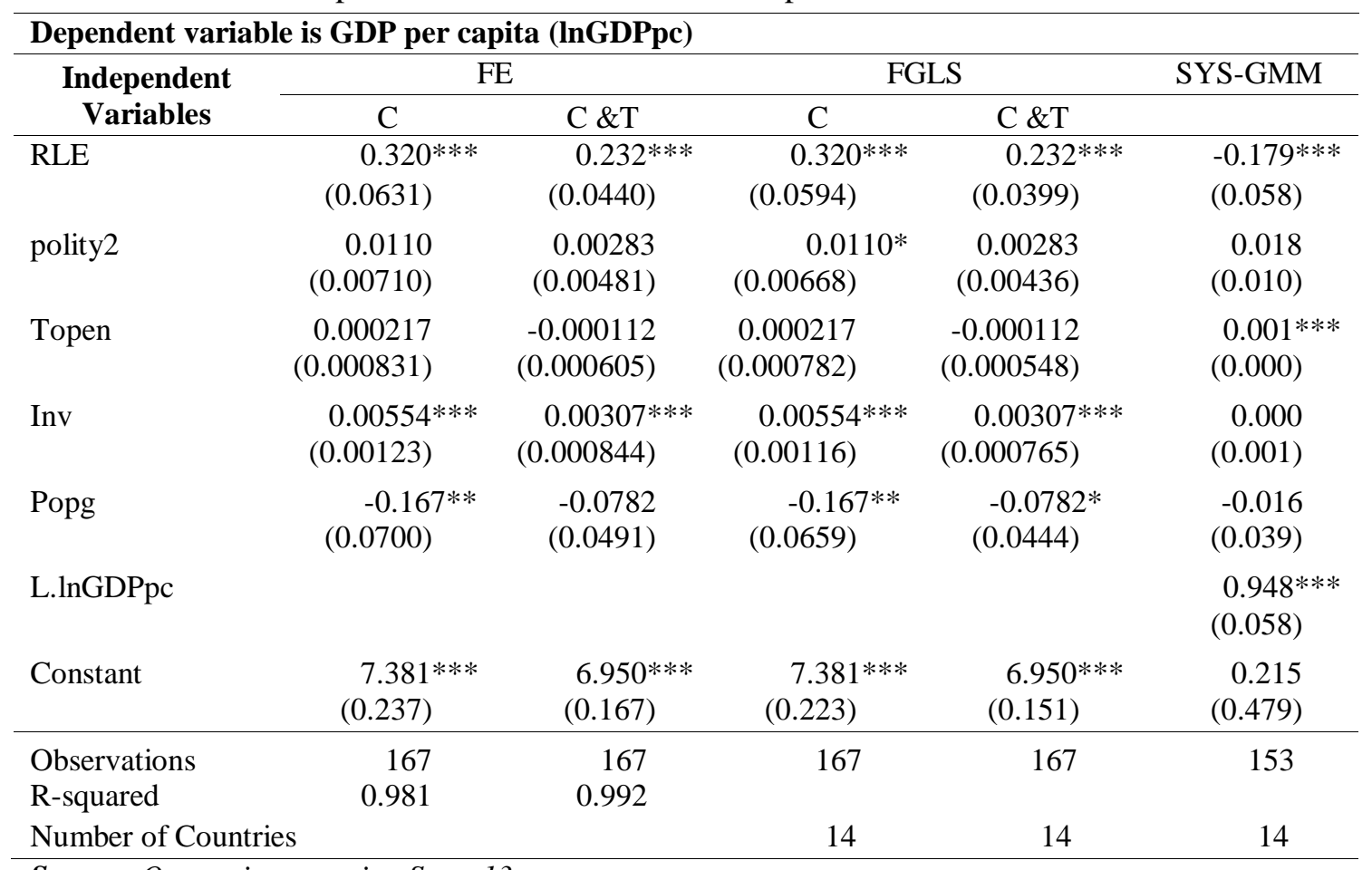

Source: Own estimates using Stata 13

Note: Standard errors in parentheses, *** $p<0.01$ means significant at $1 \%$, ** $p<0.05$ means significant at $5 \%, * p<0.1$ means significant at $10 \%$ level. Whereas, $C$ indicate country fixed effect and $C \& T$ indicate country and Time effect.

\section{CONCLUSION AND RECOMMENDATIONS}

\section{Conclusion}

The finding of this study depict that institutional quality and economic institutions in particular, has positive significant impact on economic performance of the region. To understand which institutions has the most significant impact and which institutions has lacking in the region, the effect of each individual institutional quality indicators were estimated separately, along with the investment, population growth rate ,quality of political institutions and trade openness. Accordingly, the result shows that quality of economic institutions has significant impact on economic performance, among which control of corruption and government effectives are the most important. The impact of rule of law institution in Eastern Africa has negative significant effect, while regulatory quality is lacking in the region. These impacts depend on individual and time fixed effect, which implies that each country has its own specific fixed effect that shapes economic institutions, which in turn affect economic performance by affecting individual quality of economic institutions.

\section{Recommendations}

If we see from policy perspective, government policies should pay attention on building strong institutions in terms of quality and quantity, since it is a key for further economic growth. In the light of the limitation of this study, the following implication 
will have proposed for future research; Even though this study has tried to control for deep factors that shapes quality of institutions, such as trade openness and quality of political institutions, still others factors such as income distribution, efficiency of tax system and education are not considered due to lack of data availability. Thus, study that interested to investigate the impact of institutional quality on the Eastern African Economy should focus on these factors

\section{REFERENCES}

Acemoglu, D. \& A.Robinson, J. (2010). Why Africa is Poor?. Economic History of Developing Countries, 25(1), 21-50. doi: 10.1080/20780389.2010.505010.

Acemoglu, D., Johnson, S. \& Robinson, J. A. (2005). Institutions As a Fundamental Cause of Long-Run Growth, in Durlauf, P. A. \& S. N. (ed.) Handbook of Economic Gmwth. Cambridge,Massachusetts: Elsevier B.V, 386-472. doi: 10.1016/S1574-0684(05)01006-3.

Acemoglu, D. \& Robinson, J. (2010). The Role of Institutions in Growth and Development. Review of Economics and Institutions, 1(2), 1-33. doi: 10.5202/rei.v1i2.1.

Batuo, M. E. \& Fabro, G. (2009). Economic Development, Institutional Quality and Regional integration: Evidence from Africa Countries. MPRA paper (19069).

Chang, H. (2011). Institutions and economic development: theory, policy and history. Journal of Institutional Economics, 7(4), 473-498. doi: 10.1017/S1744137410000378.

Commander, S. \& Nikoloski, Z. (2010). Institutions and economic performance: What can be explained? IZA Discussion Paper No. 5247. Available at SSRN: https://ssrn.com/abstract $=1696850$

Effiong, E. (2015). The Role of Institutions and Governance on Economic Performance in Selected sub-Saharan African Countries. M.Sc Dissertation. Department of Economics, Faculty of The Social Sciences, University of Nigeria, Nsukka

Eicher, T. \& Leukert, A. (2006). Institutions and Economic Performance: Endogeneity and Parameter Heterogeneity. Munich Discussion Paper, No. 2006-5. Available at: http://epub.ub.uni-muenchen.de/775/.

Fabro, G. \& Aixalá, J. (2009). Economic Growth and Institutional Quality: Global and Income-Level Analyses. Journal of Economic Issue, 43(4), 997-1023. doi: 10.2753/JEI002.

Fayissa, B. \& Nsiah, C. (2013). The Impact of Governance on Economic Growth in Africa The Impact of Governance On. The Journal of Developing Areas, 47(1), 91-108. doi: https://doi.org/10.1353/jda.2013.0009.

G. Marshal, M., Gurr, T. R. \& Jaggers, K. (2016). Political Regime Characteristics and Transitions, 1800-2016, Polity IV Project. Emeritus: Center For Systemic Peace, 1-60. Available at: http://www.systemicpeace.org/polity/polity4.htm.

Habtamu, F. N. (2008). Roles of Governance in Explaining Economic Growth in SubSaharan Africa. Africa Policy Journal, 1-21.

Han, X., Khan, H. \& Zhuang, J. (2014). Do governance indicators explain development performance? a cross- country analysis. ADB Economics Working Paper Series NO. 417. Mandaluyong city.

Jalilian, H., Kirkpatrick, C. \& Parker, D. (2003). Creating the conditions for international business expansion: the impact of regulation on economic growth in developing countries - a cross-country analysis. Centre on Regulation and Competition (CRC) Working papers 30689, University of Manchester, Institute 
for Development Policy and Management (IDPM).

Kaufmann, D., Kraay, A. \& Mastruzzi, M. (2010). The Worldwide Governance Indicators: Methodology and Analytical Issues. World Bank Policy Research Working Paper No. 5430. Available at: www.govindicators.org.

Kaufmann, D., Kraay, A. \& Mastruzzi, M. (2011). The Worldwide Governance Indicators: Methodology and Analytical Issues. Hague Journal on the Rule of Law, 3(2), 220-246. doi: 10.1017/S1876404511200046.

Kilishi, A. A., Mobolaji, H. I. \& Yaru, M. A. (2013). Institutions and Economic Performance in Sub-Saharan Africa: A Dynamic Panel Data Analysis. Journal of African Development, 15(2), 91-120.

Luiz, J. M. (2009). Institutions and Economic Performance: Implications for African Development. International Development, 21(1), 58-75. doi: 10.1002/jid.1472.

Nawaz, S. (2015). Growth effects of institutions : A disaggregated analysis. Economic Modelling. Elsevier B.V., 45(C), 118-126. doi: 10.1016/j.econmod.2014.11.017.

Osman, R. H., Alexiou, C. \& Tsaliki, P. (2011). The role of institutions in economic development. International Journal of Social Economics, 39(1/2), 142-160. doi: 10.1108/03068291211188910.

Rodrik, D., Subramanian, A. \& Trebbi, F. (2004). Institutions Rule: The Primacy of Institutions over Geography and Integration in Economic Development. Journal of Economic Growth, 9(2), 131-165.

Sardadvar, S. (2011). Neoclassical Growth Theory and Standard Models. SpringerVerlag Berlin Heidelberg. doi: 10.1007/978-3-7908-2637-1.

Tadić, T. (2006). Douglass C . North : Understanding the Process of Economic Change. PANECONOMICUS, 4, 487-490.

UNODC (2013). Transnational organized crime in eastern africa:A Threat Assessment. Nairobi, Kenya. doi: 44.1, p.5.

Valipoor, M. \& Bakke, F. (2016). The effects of political institutions on economic development in Sub-Saharan Africa. Master Thesis. BI Norwegian Business School.

Vitola, A. \& Senfelde, M. (2015). The Role of institutions in Economic Performance. Verslas teorija ir praktika, 16(3), 271-279. doi: 10.3846/btp.2015.498.

Wajda, E.-O. (2016). The New Institutional Economics- Main Theories. eFinanse Financial Internet Quarterly, 12(1), 78-85. doi: 10.14636/1734-039X.

Wiggins, S. \& Davis, J. (2006). Economic Institutions. IPPG Briefing paper institutions. 3. IPPG Programme Office, IDPM, School of Enviroment \& Develepment, University of Manchester 